\title{
Haemoglobin polymorphism in Atlantic cod (Gadus morhua): Allele frequency variation between yearclasses in a Norwegian fjord stock*
}

\author{
J. Mork \& G. Sundnes \\ Biological Station; N-7000 Trondheim, Norway
}

\begin{abstract}
A total of 262 specimens (0-, and 1-group) of Atlantic cod (Gadus morhua) representing 4 different yearclasses were caught in Trondheimsfjorden, Norway, during 1977-1984. They were genotyped by agar gel electrophoresis for the polymorphic haemoglobin locus $H b I$ (Sick, 1961). The analyses revealed a highly significant $(\mathrm{P}=0.0003)$ heterogeneity of $H b I$ allele frequencies between yearclasses. The difference in the frequency of the $H b I-1$ allele between the first (1977) and the last (1983) yearclass amounted to $0.18( \pm 0.07)$. The results appear to support recent reports on considerable selection effects at $\mathrm{HbI}$, and stress the unreliability of allele frequencies at this locus for use in studies of the genetic population structure of cod.
\end{abstract}

\section{INTRODUCTION}

The haemoglobin ( $\mathrm{HbI}$ ) polymorphism of Atlantic cod (Gadus morhua) was first described by Sick (1961). Subsequent studies on cod stocks throughout the species range revealed an extensive regional variation in $\mathrm{HbI}$ allele frequencies (Frydenberg et al., 1965; Sick, 1965a, b; Møller, 1968, 1969; Wilkins, 1971; Jamieson \& Jonsson, 1971; Jamieson \& Otterlind, 1971). Usually in these studies the $H b I$ allele frequencies were treated as neutral genetic markers, thus indicating a high amount of genetic substructuring in cod, even within geographically very restricted areas (cf. e.g. Møller, 1969).

On both sides of the North Atlantic, and in the Baltic Sea there are north-south clines in $\mathrm{HbI}$ allele frequencies (Frydenberg, 1965; Sick, 1965a, b). Kirpichnikov (1981) considered these clines as being supported by environmental selection, and Karpov \& Novikov (1980) provided a possible physiological basis for this by showing that the temperature effect on oxygen dissociation curves differed substantially between the three common $H b I$ genotypes. In fact there have been several reports on apparent selection effects on the $H b I$ genotypes; besides sexual differences in allele frequencies (Frydenberg et al., 1969; Mork et al, 1982), observations are reported on genotypic differences in growth (Mork et al., 1984a, b; Mork \& Sundnes, 1984), sexual maturation age (Mork et al., 1983), within-season gonad maturation (Mork et al., 1983), annual mortality (Mork et al., 1984a), and haematocrit (Mork \& Sundnes, 1984).

However, the actual effect that such phenomena, alone or in combination, may have

\footnotetext{
* Contribution No. 229, Biological Station, N-7000 Trondheim, Norway
} 
on the temporal stability of $H b I$ allele frequencies in various stocks has been only little studied. Mork et al. (1984a) reported no detectable difference of $\mathrm{HbI}$ allele frequencies in samples of adult cod taken in 1963 and 1977-80, respectively, in the Trondheimsfjord, Norway. That comparison was, however, performed on samples containing several yearclasses, in which a potential year-to-year variation may be masked. Also, potential changes of genotypic composition in yearclasses with age would tend to reduce the validity of such comparisons. Presumably, a better approach to the study of temporal stability of $\mathrm{HbI}$ allele frequencies might be performed on samples which were homogeneous with respect to age, and preferably at as low an age as practically possible.

The present study follows this approach. It deals with $\mathrm{HbI}$ allele frequency differences between yearclasses as observed among samples of 0-group and 1-group cod taken in the Trondheimsfjord, Norway, during 1977-1984.

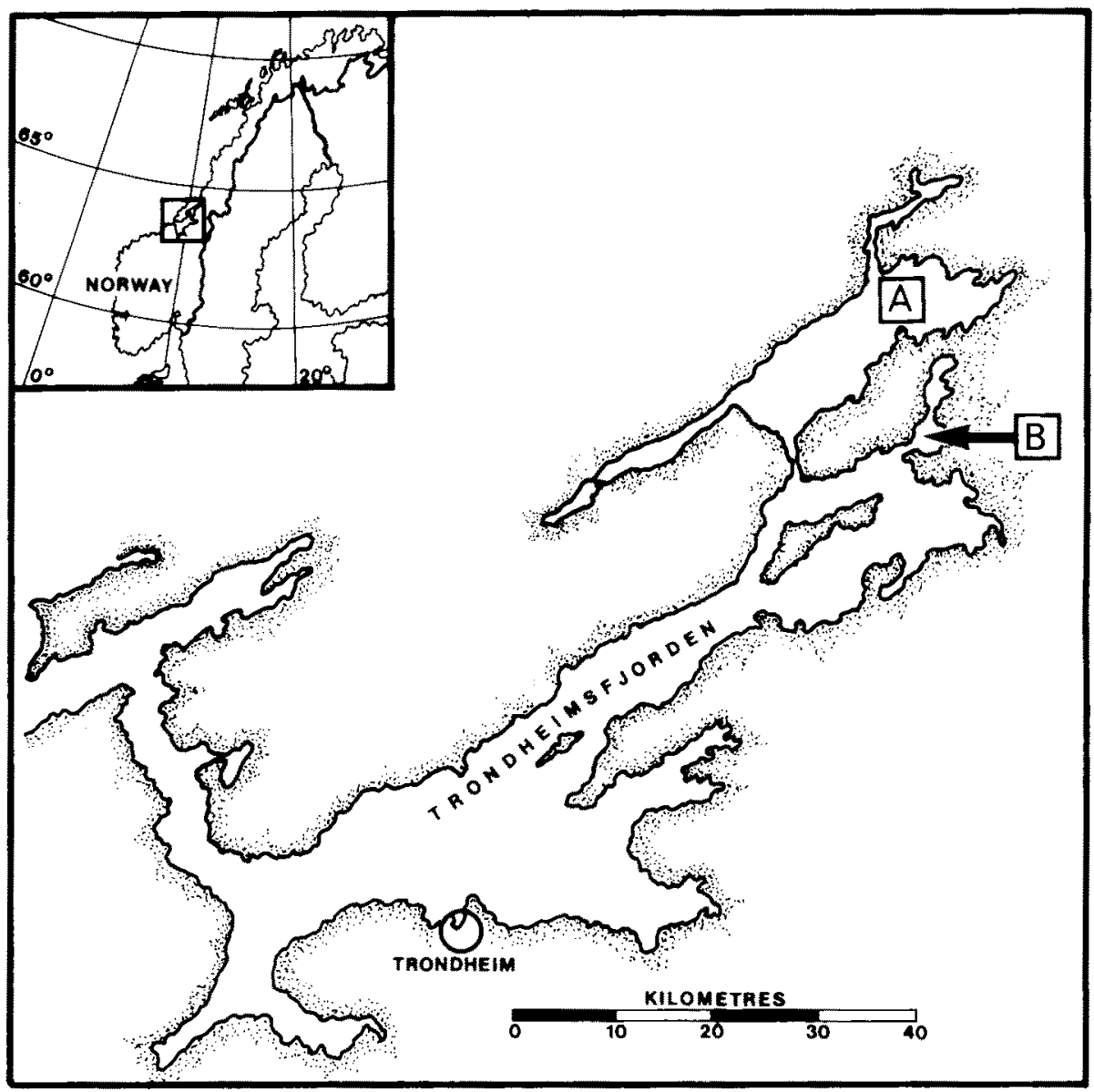

Fig. 1. Gadus morhua. Sampling locations A and B in Trondheimsfjorden, Norway 


\section{MATERIAL AND METHODS}

Samples of juvenile Atlantic cod (Gadus morhua) were collected for the present study in Trondheimsfjorden, Norway (Fig. 1). Normally, the main part of the annual spawning of cod in this fjord takes place in March, April, and May. The present offspring groups were collected in October in the year of spawning (0-group), or in March-April in the following year (1-group). 0-group specimens were collected with a beach seine in area $\mathrm{A}$, while 1-group specimens were taken with a shrimp trawl equipped with a smallmesh net at location B, a shallow side-arm to the main fjord. Further sample information is given in Table 1.

Table 1. Gadus morhua. Sample information. (See Fig. 1 for location code)

\begin{tabular}{|cccccc|}
\hline Sample & Catch date & Location & $\begin{array}{c}\text { No. of } \\
\text { specimens }\end{array}$ & $\begin{array}{c}\text { Sample } \\
\text { type }\end{array}$ & $\begin{array}{c}\text { Year } \\
\text { class }\end{array}$ \\
\hline 1 & Oct 10,1977 & A & 12 & 0 -group & 1977 \\
2 & Mar 30,1978 & B & 44 & 1 -group & 1977 \\
3 & Oct 15, 1980 & A & 7 & 0 -group & 1980 \\
4 & Oct 7, 1981 & A & 54 & 0 -group & 1981 \\
5 & Oct 12, 1983 & A & 76 & 0-group & 1983 \\
6 & Apr 27, 1984 & B & 69 & 1-group & 1983 \\
\hline
\end{tabular}

Samples from location A and B were, in part, treated separately in the statistical analyses. This was regarded as advantageous for the purpose of comparing yearclass allele frequencies, since this action simultaneously divided the material into 0-group and 1-group samples (Table 1). In addition, this action prevented bias due to potential effects of local milieu differences. The hydrography of the two sampling locations is different. In short, location $\mathrm{A}$ is situated in the main fjord where the annual temperature variation is mainly confined to the upper layers, while the annual temperature variation at location B concerns the entire water column from surface to bottom. Thus, while cod specimens at location A may escape from unpleasant temperatures by seeking deeper water where the temperature is $6-8^{\circ} \mathrm{C}$ throughout the year, specimens at location $B$ must experience temperatures ranging from $0-2{ }^{\circ} \mathrm{C}$ in winter to $16-20^{\circ} \mathrm{C}$ in summer (Mork \& Sundnes, 1984, and references therein).

There are no physical barriers between location $A$ and $B$. The exchange of pelagic eggs and larvae is probably extensive due to a strong tidal current which fills the side fjord with surface water from the main fjord. It is thus assumed that cod at location $A$ and $\mathrm{B}$ belongs to the same gene pool. Therefore, we also performed yearclass comparisons where 0-group and 1-group samples representing the same yearclass were pooled over locations.

Haemoglobin genotyping was performed by agar gel electrophoresis according to Sick (1965a), and the employed genetic nomenclature accords with Sick (1961). Individual age of specimens was checked by otolith reading according to Rollefsen (1933). The $\mathrm{G}$ (log likelihood ratio) statistic used for testing heterogeneity of proportions is described, for example, by Sokal \& Rohlf (1981). 


\section{RESULTS}

The results of the electrophoretic analyses are listed in Table 2. At both locations there was a statistically significant between-yearclass variation in $H b I$ allele frequencies (Tables 3 and 4). Although less powerful, tests of the genotypic compositions also revealed substantial heterogeneity between yearclasses at both locations (case 4 and 5 ,

Table 2. Gadus morhua. $\mathrm{Hbl}$ genotypic composition and calculated allele frequencies for year classes. Abbreviation: $q H b I-1=$ frequency of allele 1 at haemoglobin locus $I$ (sensu Sick, 1961)

\begin{tabular}{|ccrrrrr|}
\hline \multirow{2}{*}{ Location } & Yearclass & \multicolumn{5}{c|}{ No. of $H$ H genotypes } \\
& & 11 & 12 & 22 & N & $q H b I-1$ \\
\hline A & 1977 & 4 & 7 & 1 & 12 & .625 \\
A & 1980 & 4 & 3 & 0 & 7 & .786 \\
A & 1981 & 17 & 24 & 13 & 54 & .537 \\
A & 1983 & 16 & 33 & 27 & 76 & .427 \\
Sum A & $1977-1983$ & 41 & 67 & 41 & 149 & .500 \\
B & 1977 & 15 & 22 & 7 & 44 & .591 \\
B & 1983 & 10 & 34 & 25 & 69 & .391 \\
Sum B & $1977-1983$ & 25 & 56 & 32 & 113 & .469 \\
Sum A + B & $1977-1983$ & 66 & 123 & 73 & 262 & .487 \\
\hline
\end{tabular}

Table 3. Gadus morhua, Location A. Test of heterogeneity (by a $4 \times 2$ G contingency table) of $H b I$ allelic proportions in 0-group samples from 4 yearclasses. Observed and expected (in parentheses) number of alleles in each sample are listed

\begin{tabular}{|ccrrrr|}
\hline Yearclass & HbI-1 & \multicolumn{2}{c}{ HbI-2 } & 2 N \\
\hline 1977 & 15 & $(12.0)$ & 9 & $(12.0)$ & 24 \\
1980 & 11 & $(7.0)$ & 3 & $(7.0)$ & 14 \\
1981 & 58 & $(54.0)$ & 50 & $(54.0)$ & 108 \\
1983 & 65 & $(76.0)$ & 87 & $(76.0)$ & 152 \\
Sum & 149 & & 149 & 298 \\
$\mathrm{G}=10.165$, d.f. $=3, \mathrm{P}=0.017$ & & & \\
\hline
\end{tabular}

Table 4. Gadus morhua. Location B. Test (by a $2 \times 2 \mathrm{G}$ contingency table) of heterogeneity of $H b I$ allelic proportions in 1-group samples from 2 yearclasses. Observed and expected (in parentheses) number of alleles in each sample are listed

\begin{tabular}{|cccccc|}
\hline Yearclass & HbI-1 & \multicolumn{2}{c}{ HbI-2 } & $2 \mathrm{~N}$ \\
\hline 1977 & 52 & $(41.3)$ & 36 & $(46.7)$ & 88 \\
1983 & 54 & $(64.7)$ & 84 & $(73.3)$ & 138 \\
Sum & \multicolumn{2}{c}{106} & 120 & 226 \\
$\mathrm{G}=8.632$, d.f. $=1, \mathrm{P}=0.003$ & & & \\
\hline
\end{tabular}


Table 5). Nevertheless, goodness of fit G tests failed to detect deviations from HardyWeinberg expectations when these heterogeneous samples were pooled within each location (case 1 and 2, Table 5).

In none of the yearclasses represented at both locations were there any differences in genotypic or allelic proportions between $A$ and $B$ (case 6 and 7 , Table 5). Thus the

Table 5. Gadus morhua. Summary of test results. Abbreviations: $\mathrm{gf}=$ goodness of fit $\mathrm{G}$ test, $\mathrm{ct}=$ contingency table $\mathrm{G}$ test, $\mathrm{df}=$ degrees of freedom, $\mathrm{P}=$ probability. (See Table 1 for sample numbers)

\begin{tabular}{|c|c|c|c|c|c|c|}
\hline Case & Test of & $\begin{array}{l}\text { Test } \\
\text { type }\end{array}$ & Sample & $\begin{array}{c}\text { G- } \\
\text { value }\end{array}$ & df & $\mathrm{P}$ \\
\hline 1 & Hardy-Weinberg fit & $\mathrm{gf}$ & Pooled loc. A & 1.513 & 1 & 0.216 \\
\hline 2 & Hardy-Weinberg fit & $\mathrm{gf}$ & Pooled loc. B & 0.003 & 1 & 0.955 \\
\hline 3 & Hardy-Weinberg fit & gf & Pooled A+B & 0.957 & 1 & 0.328 \\
\hline 4 & $\begin{array}{l}\text { Betw. yearclass geno- } \\
\text { typic heterogeneity }\end{array}$ & $\begin{array}{l}4 \times 3 \\
\mathrm{ct}\end{array}$ & $\begin{array}{l}\text { Loc. A: all } \\
\text { samples }\end{array}$ & 11.804 & 6 & 0.066 \\
\hline 5 & $\begin{array}{l}\text { Betw. yearclass geno- } \\
\text { typic heterogeneity }\end{array}$ & $\begin{array}{l}2 \times 3 \\
\text { ct }\end{array}$ & $\begin{array}{l}\text { Loc. B: all } \\
\text { samples }\end{array}$ & 8.762 & 2 & 0.013 \\
\hline 6 & $\begin{array}{l}\text { Betw. location geno- } \\
\text { typic heterogeneity }\end{array}$ & $\begin{array}{l}2 \times 3 \\
\mathrm{ct}\end{array}$ & $\begin{array}{l}1 \text { vs } 2 \text { and } \\
5 \text { vs } 6\end{array}$ & $2.064^{*}$ & $4^{*}$ & 0.724 \\
\hline 7 & $\begin{array}{l}\text { Betw, location alle- } \\
\text { lic heterogeneity }\end{array}$ & $\begin{array}{l}2 \times 2 \\
\text { ct }\end{array}$ & As in case 6 & $0.487^{*}$ & $2 \cdot$ & 0.784 \\
\hline 8 & $\begin{array}{l}\text { Betw. yearclass geno- } \\
\text { typic heterogeneity }\end{array}$ & $\begin{array}{l}4 \times 3 \\
\mathrm{ct}\end{array}$ & $\begin{array}{l}\text { Smpls. }(1 \& 2) \\
3,4,(5 \& 6)\end{array}$ & 19.915 & 6 & 0.003 \\
\hline 9 & $\begin{array}{l}\text { Betw. yearclass } \\
\text { allelic heterogeneity }\end{array}$ & $\begin{array}{l}4 \times 2 \\
\mathrm{ct}\end{array}$ & As in case 8 & 18.803 & 3 & 0.0003 \\
\hline
\end{tabular}

different temperature regimes on the two locations (cf. "Materials and Methods") have not affected the genotypic compositions detectably. When these corresponding yearclasses were pooled over locations, the between-year-class heterogeneity of genotypic and allelic proportions was even more significant (case 8 and 9, Table 5). Still, however, the goodness of fit $\mathrm{G}$ test was unable to detect any deviation from Hardy-Weinberg expectations in the pooled material (case 3, Table 5).

There was a considerable drop in the frequency of the $H b I-1$ allele from the 1977 yearclass to the 1983 yearclass. Pooled over locations the actual frequencies were 0.598 and 0.416 , respectively, giving a difference of 0.18 (standard error 0.07 ) for this six-year period. However, it cannot be determined from the present materials whether this drop represents a general trend, or is just a fluctuation around a fairly stable long-term mean level of $\mathrm{q} H b I-1$ in this fjord stock. 


\section{DISCUSSION}

Cod $H b I$ allele frequencies in Trondheimsfjorden have been measured at irregular intervals during the last 20 years (4-5 generations). The first estimate was reported by Frydenberg et al. (1965); $\mathrm{q} H b I-1=0.485$ based on 163 specimens. The $\mathrm{q} H b I-1=0.477$ $(\mathrm{N}=851)$ reported by Mork et al. (1984a) thus did not indicate any change of allele frequencies at $\mathrm{HbI}$ in this fjord stock during 1963 and 1977-80. Both these estimates were, however, based on samples with mixed age groups.

In fact, the overall qHbI-1 for the pooled yearclasses in the present study, $0.487(\mathrm{~N}=$ 262; Table 2), is practically identical with that reported by Frydenberg et al. (1965). However, the closer inspection performed in the present study revealed an extensive genetic heterogeneity between the yearclasses which made up our samples. It appears thus that the mean $q H b I-1$ of multiple yearclasses is too coarse a measure to detect the actual fluctuations of $\mathrm{HbI}$ allele frequencies. Of course, such fluctuations can be fatal if $H b I$ allele frequencies are used as population characteristics, which in fact has been done in a number of studies on cod population structure (cf. "Introduction"). Chances are that this may have led to erroneous conclusions.

It is common practice to accept the lack of significant deviations from HardyWeinberg distribution as sufficient insurance of the genetic homogeneity at the locus under study. The present results clearly demonstrate the dangers of such practice, and the relative impotence of the goodness of fit test in the detecting of certain kinds of heterogeneity. Thus, while the $H b I$ genotypic distribution in pooled materials (last row in Table 2) appeared close to Hardy-Weinberg expectations according to the goodness of fit test, the actual heterogeneity of both genotypic and allelic proportions among the individual sub-samples was shown to be highly significant (cf. case 3 vs 8 and 9 , Table 5).

Recent studies have reported a number of fitness-related traits that may differ between cod $H b I$ genotypes in Trondheimsfjorden, e.g. growth (offspring production), annual mortality, age at maturation, and within-season gonad maturation. Some effects were sex-dependent, and sexual differences in $\mathrm{HbI}$ allele frequencies have also been reported (Mork et al., 1982, 1983, 1984a, b). Mork et al. (1984a) expected such factors to have considerable effect on $H b I$ allele frequencies among the offspring from spawning events. The present observations may be the manifestations of such effects, but certain assumptions have to be made.

One assumption is that one may ignore the contribution of potential immigrants (spawners or fry) to the year-to-year variation in $H b I$ allele frequencies. This assumption seems fulfilled: the Trondheimsfjord cod may be regarded as a self-containing unit of the Norwegian coastal cod stock. It is known that only 2 out of 46,000 recaptures from cod taggings on the Norwegian coast since 1948 have been taken in Trondheimsfjorden proper (pers. comm. with O. R. Godø, Institute of Marine Research, Bergen). As concerns pelagic eggs and larvae the estuarine circulation of the fjord will tend to carry planktonic material out of, not into, the fjord. Finally, juvenile specimens of Norwegian coastal cod have been shown to be very stationary after settling (Moksness \& Øiestad, 1980, and references therein). Thus there is no reason to expect that immigrants may have affected the present results substantially.

Another assumption concerns the potential micro-geographical segregation of $H b I$ 
genotypes according to habitat temperature regimes which was mentioned in Karpov \& Novikov (1980). Such segregation has hitherto not been documented, but if existing, it would be no less fatal than selection for the use of $\mathrm{HbI}$ allele frequencies to delineate the genetic population structure of cod. Anyhow, the sampling design of the present investigation (sampling the same locations, at the same time of the year) would presumably minimize the effect of a potential segregation and, in particular, the hydrography at location B (cf. "Materials and Methods") in fact gives cod specimens no choice with respect to temperature.

Finally, it may be mentioned that the cod stock in Trondheimsfjorden is fairly large (it supports a local fishery), and that temporal fluctuations in stock size are moderate (unpublished data). Therefore, population bottlenecks are not among the potential causes for the present results.

Thus it appears that the most likely explanation for the year-to-year variation in $H b I$ allele frequencies observed in the present study is to be found in the spectre of apparent selection effects that has previously been reported for the cod stock inhabiting Trondheimsfjorden (Mork et al., 1982, 1983, 1984a, b).

The present results support the conclusion reached by Mork et al. (1983) that cod $H b I$ allele frequencies are unreliable for use in genetic population structure analyses, and challenge the continued practice by some workers in the field (e.g. Jorstad, 1984) of interpreting $H b I$ allele frequency differences as marks of genetic isolation between groups of cod.

Besides, the present analyses have demonstrated the importance of checking samples for intrinsic heterogeneity (e.g. between yearclasses) before performing intersample testing, and have illustrated as well the low power of the goodness-of-fit test for detecting intra-sample heterogeneity.

Acknowledgements. The present study was supported by grants from the Norwegian Fisheries Research Council (I 309.07) and from Nansenfondet.

\section{LITERATURE CITED}

Frydenberg, O., Møller, D., Næevdal, G. \& Sick, K, 1965. Haemoglobin polymorphism in Norwegian cod populations. - Hereditas 53, 257-271

Frydenberg, O., Tønnes Nielsen, J. \& Simonsen, V., 1969. The maintenance of the haemoglobin polymorphism of the cod. - Jap. J. Genet. 44, 160-165.

Jamieson, A. \& Jonsson, J., 1971. The Greenland component of spawning cod at Iceland. - Rapp. P.-v. Réun. Cons. perm. int. Explor. Mer 161, 65-72.

Jamieson, A. \& Otterlind, G., 1971. The use of cod blood protein polymorphism in the Belt Sea, the Sound and the Baltic Sea. - Rapp. P.-v. Réun. Cons. perm. int. Explor. Mer 161, 55-60.

Jorstad, K, 1984. Genetic analyses of cod in Northern Norway. - Flødevigen Rapp. 1, 745-760.

Karpov, L. K. \& Novikov, G. G., 1980. The haemoglobin alloforms in cod (Gadus morhua L.), their functional characteristics and distribution in the populations. (Transl from Russian). - Vopr. Ikthiol. 20, 823-827.

Kirpichnikov, V. S., 1981. Genetic bases of fish selection. Springer, Berlin, 410 pp.

Møller, D., 1968. Genetíc diversity in spawning cod along the Norwegian coast. - Hereditas 60 , $1-32$.

Møller, D. 1969. The relationship between arctic and coastal cod in their immature stages illustrated by frequencies of genetic characters. - FiskDir. Skr. (Havunders.) 15, 220-233.

Moksness, E. \& Øiestad, V., 1980. Tagging experiments on 0-group coastal cod (Gadus morhua L.) reared in an outdoor basin. - Fisken Hav, 4, 11-20. 
Mork, J. \& Sundnes, G., 1984. Haemoglobin polymorphism in Gadus morhua: genotypic differences in haematocrit. - Helgoländer Meeresunters. 38, 201-206.

Mork, J., Reuterwall, C., Ryman, N. \& Ståhl, G., 1982. Genetic variation in Atlantic cod (Gadus morhua L.): a quantitative estimate from a Norwegian coastal population. - Hereditas 96, 55-61.

Mork, J., Giskeødegård, R. \& Sundnes, G., 1983. Haemoglobin polymorphism in Gadus morhua: genotypic differences in maturing age and within-season gonad maturation. - Helgoländer Meeresunters. 36, 313-322.

Mork, J., Giskeødegård, R. \& Sundnes, G., 1984a. Population genetic studies in cod (Gadus morhua L.) by means of the haemoglobin polymorphism; observations in a Norwegian coastal population. - FiskDir. Skr. (Havunders.) 17, 449-471.

Mork, J., Giskeødegård, R. \& Sundnes, G., 1984b. The haemoglobin polymorphism in Atlantic cod (Gadus morhua L.); genotypic differences in somatic growth and in maturing age in natural populations. - Flødevigen Rapp. 1, 721-733.

Rollefsen, G., 1933. The otoliths of the cod. - FiskDir. Skr. (Havunders.) 4(3), 1-14.

Sick, K., 1961. Haemoglobin polymorphism in fishes. - Nature, Lond. 192, 894-896.

Sick, K., 1965a. Haemoglobin polymorphism of cod in the Baltic and Danish Belt Sea. - Hereditas $54,19-48$.

Sick, K., 1965b. Haemoglobin polymorphism of cod in the North Sea and the North Atlantic Ocean. - Hereditas 54, 49-69.

Sokal, R. R. \& Rohlf, F. S., 1981. Biometry. Freeman, San Francisco, 859 pp.

Wilkins, N, P., 1971. Haemoglobin polymorphism in cod, whiting and pollack in Scottish waters. Rapp. P.-v. Réun. Cons. perm. int. Explor. Mer 161, 60-64. 